INDEPENDENT JOURNAL OF MANAGEMENT \& PRODUCTION (IJM\&P)

http://www.ijmp.jor.br

v. 11, n. 4, July - August 2020

ISSN: 2236-269X

DOI: 10.14807/ijmp.v11i4.1136

\title{
IMPLICATIONS OF ADDITIVE MANUFACTURING ON SUPPLY CHAIN AND LOGISTICS
}

\author{
Daniel R. Tasé Velázquez \\ Methodist University of Piracicaba (UNIMEP), Brazil \\ E-mail:dtasev88@gmail.com \\ Alexandre Tadeu Simon \\ Methodist University of Piracicaba (UNIMEP), Brazil \\ E-mail: alexandre.simon@unimep.br \\ André Luís Helleno \\ Methodist University of Piracicaba (UNIMEP), Brazil \\ E-mail: alhelleno@unimep.br \\ Lorena Hernández Mastrapa \\ Methodist University of Piracicaba (UNIMEP), Brazil \\ E-mail: lorenahmastrapa@gmail.com
}

Submission: $10 / 8 / 2019$

Accept: 10/22/2019

\section{ABSTRACT}

Additive manufacturing (AM) technology has attracted the interest of industrial professionals and researchers in the last years. This interest lies primarily in understanding the trends, benefits, and implications of AM technology on supply chain (SC) and logistics, as it requires reconfiguring the supply chain based on a distributed manufacturing strategy, closer to the consumer market, with shorter lead times and less raw materials. It still is an emerging field, and needs further study. Therefore, a better understanding of main trends will contribute to the dissemination of knowledge about AM technology and its consolidation. This article seeks to investigate the implications of AM, as an advanced manufacturing model, on SC and logistics. A four-step research method was used to develop a systematic literature review and a bibliometric analysis on the AM implications in SC and logistics. The main implications of AM on SC and logistics were classified in seven key issues gathered as result of the literature review. Additionally, bibliometric study allowed understanding researches major trends in this field. 
DOI: 10.14807/ijmp.v11i4.1136

The key aspects highlighted and characterized as major implications of AM on SC and logistic are: supply chain complexity reduction; more flexible logistics and inventory management; better spreading and popularization of mass customization; decentralization of manufacturing; greater design freedom and rapid prototyping; increasing of resource efficiency and sustainability, and the need to have clearly defined legal and safety aspects.

Keywords: Additive manufacturing, Supply chain, Logistics

\section{INTRODUCTION}

Additive manufacturing (AM), popularly referred as 3D printing, enables the fabrication of parts and components with complex surfaces (LASEMI et al., 2010), also known as freeform surfaces (GUO; LEU, 2013). AM processes and techniques generally employ a bottom-up fabrication approach (TOFAIL et al., 2018), where a structure can be fabricated by means of selective material deposition/addition process known layer-by-layer (DUTTA et al., 2011).

By means of AM processes adoption, companies have experienced a high degree of flexibility and agility in changing production schedules, which in turn, has allowed better resources and raw materials use, leading to an operating cost reduction (GUESSASMA et al., 2015). Another distinctive factor associated to AM is the increasingly products' rapid transfer to the market. The time reduction in product design and manufacturing are aspects required by strict clients that follows the volatile marketing trends (QUAN et al., 2015).

AM makes flexible the manufacture of highly customized products in a competitive time, with low volume, high-added value and competitive production costs. AM is generally used for producing unique products and small batches (one unit batch). This contributes significantly for reducing the product delivery-time to end-users (GAO et al., 2015).

The implications of AM on supply chain and logistics activities have been the subject of some researches. Hannibal and Knight (2018) discuss the potential impact of additive manufacturing on global production chains and logistics activities from the point of view of "global factory” (BUCKLEY; GHAURI, 2004; BUCKLEY, 2009a; BUCKLEY, 2009b; BUCKLEY, 2011) and “localization of production” concepts.

Concerning that, they argue that a major advantage of AM could be the costs reduction in transportation and logistics activities, provided since production could take place in an ecosystem outside the company boundaries, which in turn, allows manufacturing products in a closer manner to end-user and consumers. 
INDEPENDENT JOURNAL OF MANAGEMENT \& PRODUCTION (IJM\&P)

http://www.ijmp.jor.br

v. 11, n. 4, July - August 2020

ISSN: $2236-269 X$

DOI: $10.14807 /$ ijmp.v11i4.1136

Campbell et al. (2011) and Laplume et al. (2016) suggest that AM can affect the firms role for coordinating global value chains and could lead to high-volume, small-scale production at a local level (on-site/on-demand production) with minimal costs of set-ups and reprocessing allowing the reduction of the logistics activities and shorter supply chains.

The "localization of production" using AM technologies allows to manufacture customized products with design flexibility at the appropriate cost, under the requirements of environmental conservation and taking into account the users possibility to modify/customize the final product as by them required (HANNIBAL; KNIGHT, 2018). Strange and Zucchella (2017) suggest that the potentials of AM technologies on SC and logistics is probably related to the coupling of AM with other technological advances such as industry 4.0.

The relevance and popularization of AM processes in the industrial sector, increases the academic interest in understanding the benefits and implications of AM on SC and logistics. This work seeks to investigate which are the implications of the AM on SC and logistics as its popularization as and advanced manufacturing model. A systematic literature review was carried out, which allowed synthesizing the contributions in this research subject. A bibliometric study was also used to reveal the current state of researches in this field.

This this work is organized in fourth sections. The introduction, which contextualize and presents the paper research interest and main objective; the research method is discussed in the next section; results and discussion, as the third one, includes a documental analysis, bibliometric study and main AM implications on the research context are detailed; and final considerations are settled at the last one.

\section{RESEARCH METHOD}

In order to gather the main scientific documents related to the study of AM implications on SC and logistics, a four-step research method described below was adapted from Fahimnia et al. (2015).

Step 1. Search terms definition: for gathering the most relevant papers, were identified nine keywords after reviewing in non-structured manner some works related to the study area. These keywords are additive manufacturing, 3D printing, three-dimensional printing, rapid prototyping, rapid manufacturing, digital manufacturing, direct digital manufacturing, supply chain and logistics. 
DOI: 10.14807/ijmp.v11i4.1136

Step 2. Search strategy and protocol: the bibliographic search was done by following the protocol in Table 1. Remaining terms belonging to AM context were used as inclusion criteria for papers search refining.

Table 1: Search protocol and inclusion/exclusion criteria

\begin{tabular}{l}
\hline \multicolumn{1}{|c|}{ Search protocol } \\
\hline String (i): "additive manufacturing" AND "supply chain" AND "supply chain implications" \\
String (ii): "additive manufacturing" AND "logistics" AND "logistics implications" \\
Inclusion (I) / exclusion (E) filters \\
(I) Exact strings' terms, found in any part of the document \\
(I) Publishing period: 2010 - 2019 \\
(I) Type of material and language: scientific articles written in English \\
(I) Papers containing terms related to: "additive manufacturing”, “3d printing”, "supply chains" "rapid \\
prototyping”, "three dimensional printing”, "Logistics” \\
(I) Peer reviewed papers only \\
(E) Excluding books and duplicated papers \\
(I) Include papers after analysis, through manual screening of the title, abstract, keywords and theoretical or \\
practical contributions. \\
(E) Exclude articles outside of research scope (no-scientific magazine articles, encyclopedias, commercial \\
publications, industrial viewpoints, etc.)
\end{tabular}

Step 3. Database selection: authors selected the renowned databases such as Science Direct, Emerald Insight, Springer Link, Web of Science, Wiley Online Library and SAGE Journals. These six platforms allowed finding and analyzing major papers related to the study area. The "snowballing” approach for literature search was also used, but it was not found any interest paper.

Step 4. Data analysis: an inductive approach (MIGUEL, 2012) was used to formulate conclusive criteria from bibliometric study developed. Complementing the analysis, Mendeley software was used to extract the articles bibliographic data, which was exported to a spreadsheet in order to complement bibliometric analysis, and then processed in the BibExcel software. The main AM implications on SC and logistics covered in the 75 articles were also detailed.

\section{RESULTS AND DISCUSSIONS}

\subsection{Documental and Bibliometric Analysis}

The literature review was developed until September 2019. From the search strings, the quantity of articles resulted in 13 361. This amount of documents was gradually reduced by applying inclusion/exclusion qualifier filters to finally gather 75 articles that were considered relevant to the research as detailed in Table 2. 
Table 2: Search protocol applied

\begin{tabular}{|c|c|}
\hline Search protocol & Papers \\
\hline $\begin{array}{l}\text { String (i) "additive manufacturing” AND "supply chain” AND "supply chain implications" } \\
\text { String (ii) "additive manufacturing” AND "logistics" AND "logistics implications”. }\end{array}$ & 13361 \\
\hline Qualifier filters: Inclusion (I) / exclusion (E) & \\
\hline $\begin{array}{l}\text { (I) Exact strings terms with presence in any part of the document } \\
\text { (I) Publishing period: last } 10 \text { years (2010 - 2019) } \\
\text { (I) Type of material: scientific articles only } \\
\text { (I) Language: English only } \\
\text { (E) Exclude books } \\
\text { (I) Papers related to: "additive manufacturing”, "3d printing”, "supply chains" "rapid prototyping”, } \\
\text { "three dimensional printing”, "Logistics" } \\
\text { (I) Peer reviewed papers only } \\
\text { (E) Other resources online }\end{array}$ & 288 \\
\hline $\begin{array}{l}\text { (I) Include papers after analysis, through manual screening of title, abstract, keywords and with } \\
\text { theoretical and/or practical contributions. } \\
\text { (E) Exclude articles outside of research scope (no-scientific magazine articles, encyclopedias, } \\
\text { commercial publications, industrial viewpoints, etc.) }\end{array}$ & 75 \\
\hline
\end{tabular}

Preliminary results of literature search allows concluding that published scientific papers about implications of AM on SC and logistics are still limited despite the relevance and novelty of this topic. This may be conditioned by the limited accessibility to the industrial structure needed to deploy manufacturing models based on additive manufacturing, which consequently limits research works related to advances in the field, as this is a relatively "young" field.

\subsubsection{Keywords Visualization and Papers Publishing Trends}

Keywords mentioned in each article were extracted from Mendeley software and the frequency controlled by BibExcel software. In total, 365 keywords were identified. Figure 1 shows the frequency appearance of the 365 keywords, as the VOSviewer software was used for this purpose.

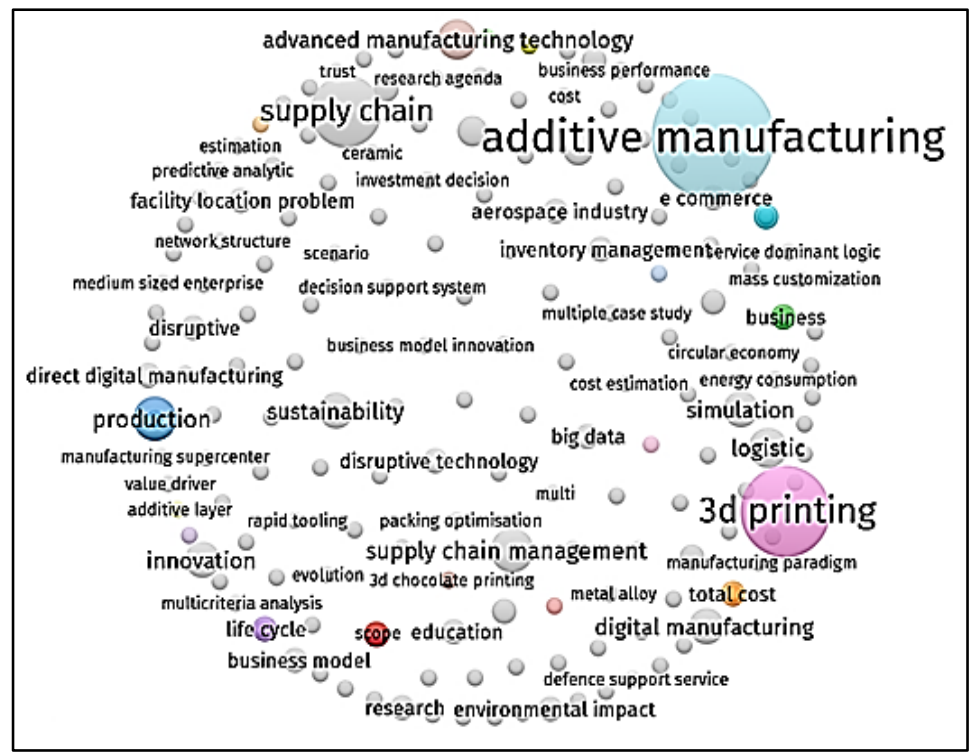

Figure 1: Keywords mentioned with higher frequency 
DOI: $10.14807 /$ ijmp.v11i4.1136

In Figure 1 can be observed that the circles associated with the most frequent mentioned keywords in articles appear larger. The terms "additive manufacturing”, "3D printing” and "supply chain" appear with larger size in this order. In a lower size, appear terms such as "logistic”, “production”, “supply chain management”, “sustainability”, “innovation”, and "advanced manufacturing technology". This may indicate a growing interest in disseminating knowledge about how AM can contribute to and/or affect production, commercial and technological processes while continuing to address sustainability issues.

Analyzing the 75 selected papers was possible to identify the publishing trend per year as shown in Figure 2.

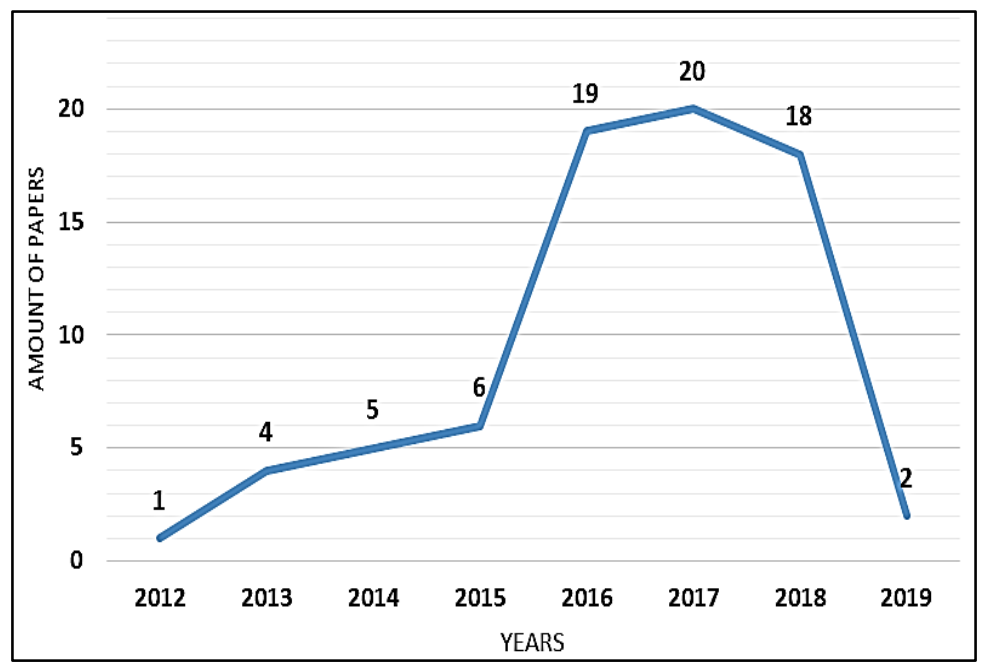

Figure 2: Publishing paper trends and quantity per year

As observed in Figure 2, only from 2012 until the reviewing period in 2019, the tendency was increasing, although, from 2017 to 2019 it decreased. It could been conditioned by the fact that 2019 has not finished. The gap in years prior to 2012 may be a consequence of the consolidation of traditional manufacturing systems in the industry and the incipient knowledge on the benefits of employing AM as an advanced manufacturing model. This can being corroborated in the study-report developed by the United States Institute for Defense Analysis in 2012 (IDA, 2012). In this study AM was identified as one of the emerging trends in advanced manufacturing technologies, and as future scenarios the need of manage the increasingly complex global supply chains and its risks, given the gradual increase of hightechnology goods demand.

\subsubsection{Main Publishing Journals}

The publishing journals were been identified totalizing 42 different journals. Figure 3 shows the 14 journals with more than one publication and the quantity of paper published per 
ISSN: 2236-269X

DOI: 10.14807/ijmp.v11i4.1136

year from 2012 to 2019 in decreasing order, counting 47 papers. As can be seen in Fig. 3, the highlighted journal by quantity of publications is the "Journal of Manufacturing Technology Management” with 11 papers. In remaining 28 journals, only was published one article.

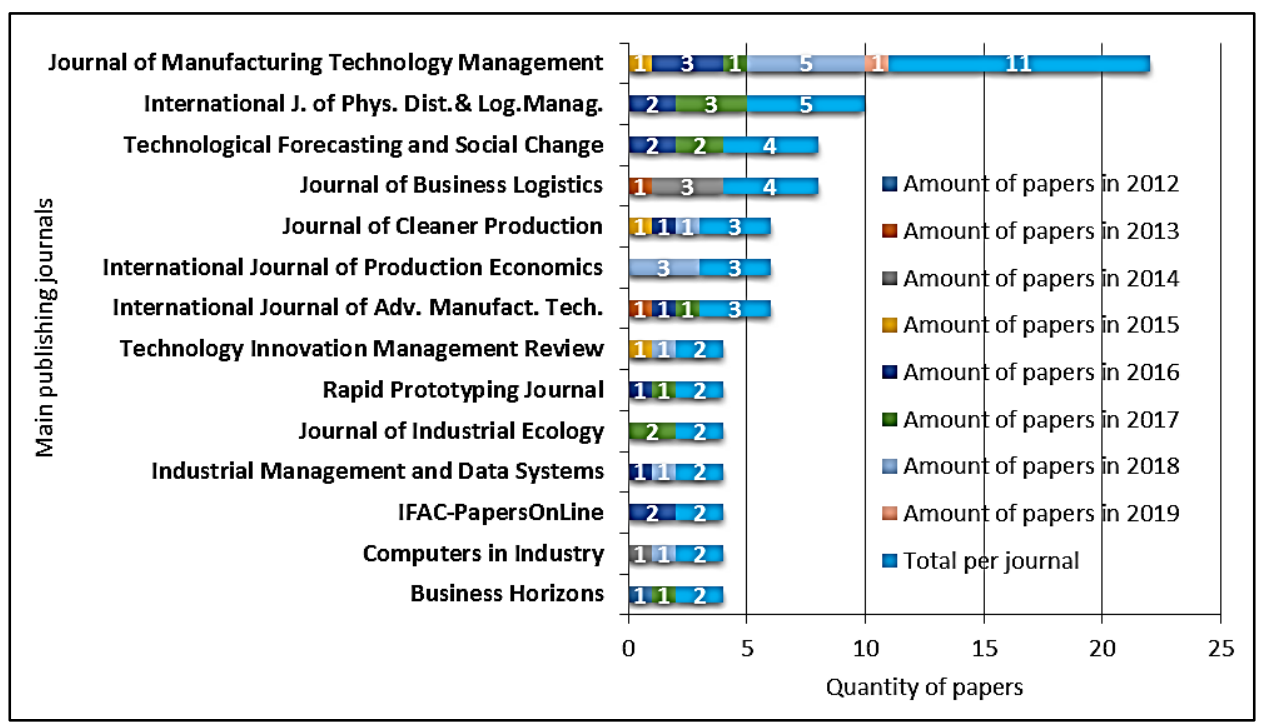

Figure 3: Main publishing journals, quantity of papers per year and total per journal

\subsubsection{Authors Analysis, International and Institutional Representation}

The authors' data were been extracted and frequency of authoring was observed in publications. Only 28 authors of the 243 identified appear in two or more publications and in a maximum of five. Figure 4 presents authors*/co-authors** as well as the quantity of papers published, respectively, among of 75 gathered.

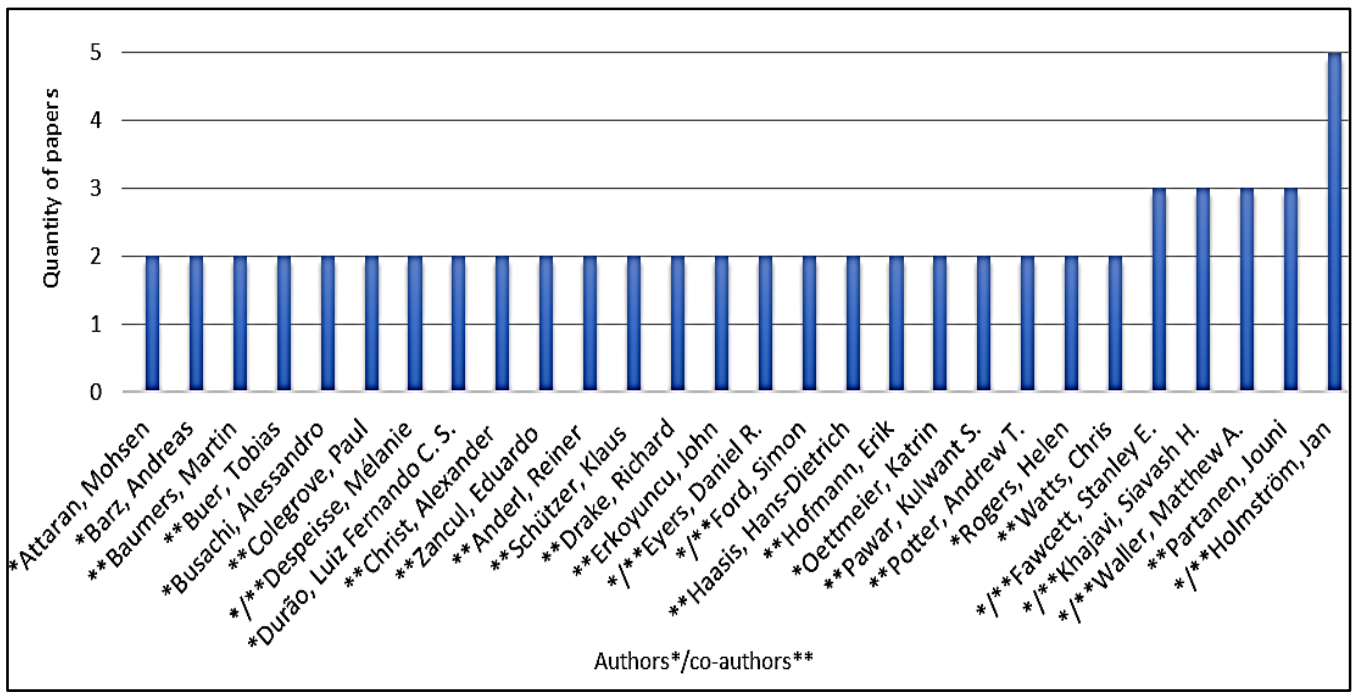

Figure 4: Authors*/co-authors** and quantity of papers published

It is necessary to mention that some of the authors with two or more publications are not the main authors but co-authors. Highlighted with a star $\left(^{*}\right)$ is referred the first author, and with two stars $(* *)$ the co-authors with more than one publication. 
ISSN: 2236-269X

DOI: 10.14807/ijmp.v11i4.1136

The most contributing countries by quantity published papers selected were extracted. Figure 5 indicates the 23 countries with greater representativeness, and quantity of papers, respectively, sorted clockwise in descending order. It can be seen that three countries represent the highest density, being the United States of America (USA), United Kingdom (UK) and Germany (GER).

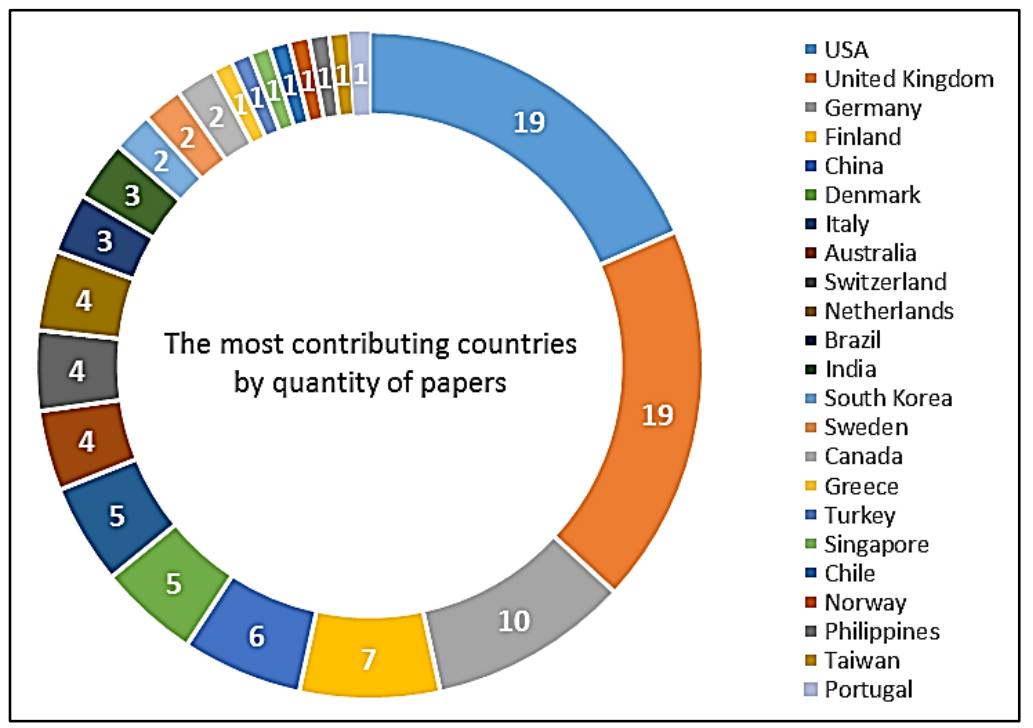

Figure 5. Countries with the highest contribution and quantity papers

Consequently, researchers were affiliated to 107 institutions. Main 19 universities collaborate with publishing more than one article. It was noticed the existence of a wide heterogeneity of the institutions involved. Figure 6 shows the most contributing institutions by quantity of papers. It can be noted that UK appears with five universities, whereas GER and USA appear with four, followed by Brazil and Denmark with two, and Finland and Switzerland with one.

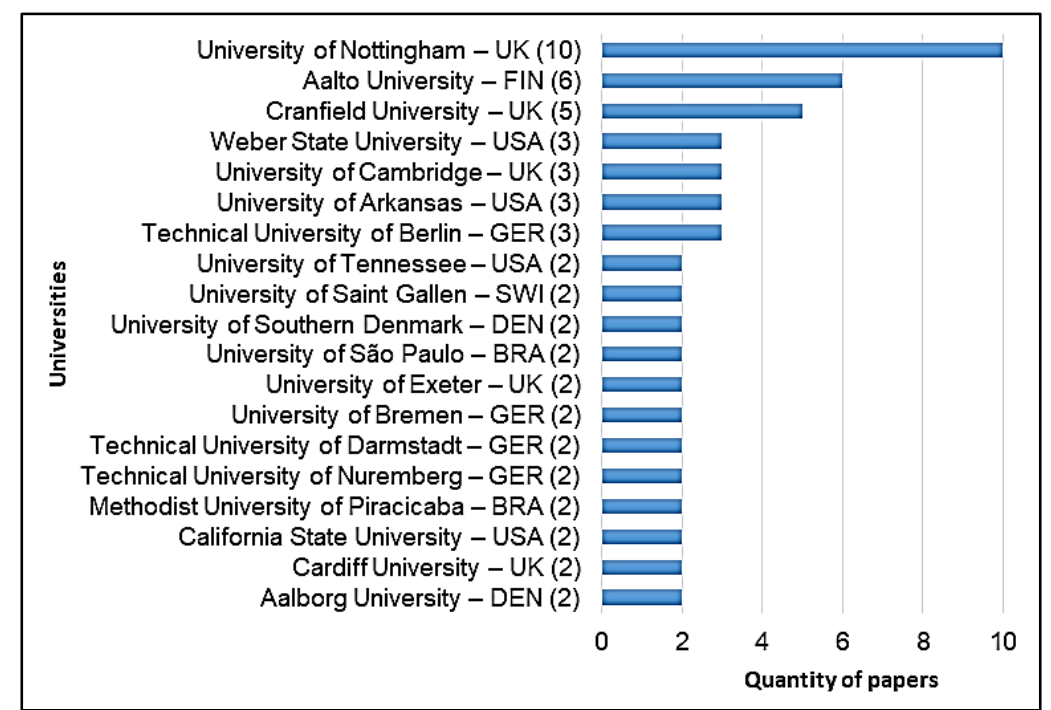

Figure 6. Universities with higher contribution by quantity of papers 
DOI: 10.14807/ijmp.v11i4.1136

\subsection{Implications of AM on Supply Chain and Logistics}

After analyzing the technical and research's contributions of the 75 articles gathered, seven major implications of AM on SC and logistics context, as part of technological and production advances in these areas were outlined as follow:

- Supply chain complexity reduction (CR): Reducing chain complexity is due to increased capacity to produce products in a single-full unit eliminating the need to assemble multiple components. This, consequently, reduces the need of stock replacement parts given the low quantity of raw material needed to produce a product. It also reduces the amount of work activities, internal production costs (internal transport, labor, etc.), shorten the production process flow and allows better materials control (which are minimal in variety) (GAO et al., 2015; JANSSEN et al., 2014).

- Safety and legal aspects (S-LA): Given the ability of these technologies to produce many types of goods, there is a need to guarantee and control the production and nonfalsification of products that could cause harm to humans, for example, firearms, bladed-weapons, etc. Massive and rapid sharing of files containing physical scanned products requires adequate control because the current legal framework for 3D printing does not consider guidelines for the regulated scanning of physical objects (NYMAN; SARLIN, 2014).

- Flexible logistics services and inventory management (FL-IM): AM can affect the role of companies in coordinating global value chains and can lead to high local-level production (on-site/on-demand production) with minimal cost related to set-ups and reprocessing. This in-situ production model (localized production), or near at the final consumption place, reduces the quantity of logistics transportation activities and associated costs. It turns out to be a futuristic trend in replacing inventories of physical products and raw materials with digital inventories in form of 3D .stl files. Fewer raw materials will require less skilled personnel for handling, so the cost of holding inventories drops considerably (MOHR; KHAN, 2015).

- Mass customization (MC): Ben-Ner and Siemsen (2017) point out that the end-result of the impact of AM technologies on production systems may be the popularization of mass customization, as opposed to the current paradigm of mass production. AM technology allows the production of customized products, with design flexibility at an appropriate cost and meeting environmental conservation requirements. Localized 
DOI: 10.14807/ijmp.v11i4.1136

production through AM gives users the ability to access to the product on the time required by them and allows end-users themselves to incorporate design changes and customize products to meet their own very-specific needs. This design-changing activities does not implies additional re-processing costs, instead, it just require programming changes in digital files.

- Decentralization of manufacturing (DM): The benefits that AM can bring to global value chains include the easy on-site production and consuming, as well as ensuring faster responses to changes on demand, helping to reduce time to market. New products can been design faster, and delivered to customers faster. AM can increase the responsiveness of companies to manufacturing products in hard-to-reach places or in disasters situations by developing technologies for humanitarian logistics activities (SAVONEN et al., 2018), and distributed production systems. By locally manufacturing or employing distributed manufacturing models close to customers, companies can be faster and more responsive in their strategic manufacturing activities and costs reduction in supply chain set-up.

- Design freedom and rapid prototyping (DF-P): AM linked to information and communication technologies and other modalities such as industry 4.0, web 2.0, big data, internet of things (IoT), etc. announce the beginning of a new era in global production through the digitization of goods (GAO et al., 2015; STRANGE; ZUCCHELLA, 2017). 3D printing technology is so versatile that it can produce a vast range of fundamentally different items, in an easily manner and quickly. As a future trend, due to easily-to-produce, end-users will be involved in production of selfdemanded products (MOHR; KHAN, 2015).

- Resource efficiency and sustainability (RE-S): Regarding to resource efficiency, in order to achieve adequate levels of environmental and production sustainability, it have been recommended the observation of wastes handling and environmental regulations. In terms of energy consumption, AM processes generally has lower impact than conventional manufacturing processes such as machining, milling, etc. (HUANG et al., 2013). The reconfiguration of shorter and more collaborative value chains aims to guarantee the extension of product life through technical approaches such as repair, remanufacturing and reconditioning, ensuring more sustainable socioeconomic patterns and closer relations between producers and consumers (KOHTALA; HYYSALO, 
INDEPENDENT JOURNAL OF MANAGEMENT \& PRODUCTION (IJM\&P)

http://www.ijmp.jor.br

v. 11, n. 4, July - August 2020

ISSN: 2236-269X

DOI: 10.14807/ijmp.v11i4.1136

2015). This saves monetary capital by reducing the need to use high-cost materials for manufacturing new parts.

Table 3 highlights and classify by paper, the key issues covered about the implications of AM on SC and logistics following the seven major trends identified earlier.

Table 3: Key issues covered in papers about AM implications on SC and logistics

\begin{tabular}{|c|c|}
\hline Authors & Key AM implications on SC and Logistics \\
\hline BERMAN (2012) & $\begin{array}{l}\text { DF-P/MC - Key features and applications of 3D printing, mass customization } \\
\text { and comparison for rapid prototyping with traditional manufacturing methods. }\end{array}$ \\
\hline HUANG et al. (2013) & $\begin{array}{l}\mathrm{CR} / \mathrm{DM} \text { /MC/RE-S - Characterization of AM approaches. Analysis of impacts } \\
\text { on population's health and wellbeing and environmental impacts in terms of } \\
\text { energy consumption, as well as, the possibility of revolutionizing the delivery } \\
\text { of AM products through supply chain reconfiguration. }\end{array}$ \\
\hline RAY (2013) & $\begin{array}{l}\text { CR - Benefits analysis of the simultaneous and real-time management of supply } \\
\text { and demand chains. }\end{array}$ \\
\hline SILVA and REZENDE (2013) & FL-IM - Overview of AM area and its expected impact in logistics. \\
\hline $\begin{array}{l}\text { WALLER and FAWCETT } \\
\text { (2013) }\end{array}$ & CR - Disruptive trends in supply chain. \\
\hline $\begin{array}{l}\text { CHRISTOPHER and RYALS } \\
\text { (2014) }\end{array}$ & $\begin{array}{l}\text { FL-IM - Emerging trends in supply chain managements with lower inventory } \\
\text { and fast customer response with waste and obsolescence reduced. }\end{array}$ \\
\hline $\begin{array}{l}\text { FAWCETT and WALLER } \\
\text { (2014) }\end{array}$ & CR/S-LA - Potential supply chain design inflection points. \\
\hline KHAJAVI et al. (2014) & $\begin{array}{l}\text { DM - Evaluate the potential impact of additive manufacturing improvements on } \\
\text { the configuration of spare parts supply chains and costs. }\end{array}$ \\
\hline $\begin{array}{l}\text { HOLMSTRÖM and } \\
\text { PARTANEN (2014) }\end{array}$ & $\begin{array}{l}\text { DF-P/CR/FL-IM - Exploration of how combination of digital manufacturing, } \\
\text { logistics and equipment use affect the relationship among logistics service } \\
\text { providers, users and manufacturers of equipment. }\end{array}$ \\
\hline $\begin{array}{l}\text { WALLER and FAWCETT } \\
(2014)\end{array}$ & $\begin{array}{l}\mathrm{CR} / \mathrm{MC} / \mathrm{FL}-\mathrm{IM} \text { - Disruptive forces and significant implications for practice, } \\
\text { research, and teaching in supply chain management. }\end{array}$ \\
\hline ACHILLAS et al. (2015) & $\begin{array}{l}\text { DF-P - Decision-making methodological framework for selecting AM } \\
\text { techniques in substitution of traditional manufacturing technologies. }\end{array}$ \\
\hline CHEN et al. (2015) & $\begin{array}{l}\text { RE-S/CR - Main aspects of direct digital manufacturing and sustainability } \\
\text { implications, supply chain, transportation. }\end{array}$ \\
\hline EYERS and POTTER (2015) & CR - Use of e-commerce with AM, benefits through increased efficiency and \\
\hline GAO et al. (2015) & $\begin{array}{l}\text { cost reductions in information transfer, SC disintermediation. Review of current } \\
\text { barriers, findings, and future trends in AM. }\end{array}$ \\
\hline $\begin{array}{l}\text { GRESS and KALAFSKY } \\
(2015)\end{array}$ & $\begin{array}{l}\text { CR/DM - Opportunities for theoretical explorations and research on additive } \\
\text { manufacturing and its impacts on the integration with, traditional } \\
\text { manufacturing, supply, demand, innovation and global production networks. }\end{array}$ \\
\hline TATHAM et al. (2015 & DM - Potentials for AM to support the preparation and response activities for \\
\hline BALDINGER et al. (2016) & $\begin{array}{l}\text { complex situations in humanitarian context. Develop suitable cost estimation } \\
\text { models for AM focusing on buy scenarios and SC setup. }\end{array}$ \\
\hline BARZ et al. (2016a, 2016b) & $\begin{array}{l}\text { RE-S - AM high resource efficiency and quantitative assessment of the effects } \\
\text { on the supply networks structure. }\end{array}$ \\
\hline BOGERS et al. (2016) & $\begin{array}{l}\text { DM/MC - Business model moving from a manufacturer-centric to a consumer- } \\
\text { centric by manufacturing. }\end{array}$ \\
\hline CHEN (2016) & $\begin{array}{l}\mathrm{DM} / \mathrm{CR} / \mathrm{FL}-\mathrm{IM} \text { - An international SC model using system dynamics method to } \\
\text { simulates its reconstruction trend by studying its spatial and temporal variation } \\
\text { in the worldwide range after 3D printing model application. }\end{array}$ \\
\hline CHIU and LIN (2016) & $\begin{array}{l}\mathrm{DM} / \mathrm{MC} / \mathrm{DF}-\mathrm{P} \text { - Development of a decision support tool (DfAM - design for } \\
\text { additive manufacturing) for optimizing personalized products under demand } \\
\text { uncertainties. }\end{array}$ \\
\hline $\begin{array}{l}\text { FORD and DESPEISSE } \\
(2016)\end{array}$ & $\begin{array}{l}\text { RE-S - Discussion about AM implications on sustainability concerning to } \\
\text { innovation, business models and value chains configuration. }\end{array}$ \\
\hline HOLMSTRÖM et al. (2016) & $\begin{array}{l}\text { CR/DM - Main challenges of AM and its research agenda at factory, supply } \\
\text { chain, and operations strategy level. }\end{array}$ \\
\hline
\end{tabular}




\section{INDEPENDENT JOURNAL OF MANAGEMENT \& PRODUCTION (IJM\&P)}

http://www.ijmp.jor.br

v. 11, n. 4, July - August 2020

ISSN: 2236-269X

DOI: 10.14807/ijmp.v11i4.1136

JIA et al. (2016)
KNOFIUS et al. (2016)
KOTHMAN and FABER
$(2016)$

LI et al. (2016)

MACCARTHY et al. (2016)

OETTMEIER

HOFMANN (2016; 2017)

POUR et al. (2016)

BEN-NER and SIEMSEN

(2017)

ROGERS et al. (2016)

SASSON and JOHNSON (2016)

SIRICHAKWAL

CONNER (2016)

THOMAS (2016)

ATTARAN (2017a, 2017b)

BUSACHI et al. (2017)

DURÃO et al. (2016; 2017)

DESPEISSE et al. (2017)

DURACH et al. (2017)

FELDMANN and PUMPE (2017)

HANDAL (2017)

HOLMSTRÖM

GUTOWSKI (2017)

HUANG ET AL. (2017)

JIANG et al. (2017)

NIAKI and NONINO (2017)

ÖZCEYLAN et al. (2018)

PARITALA et al. (2017)

KHAJAVI et al. (2018)

ROGERS et al. (2017)

RYAN et al. (2017)

BUSACHI et al. (2018)

STRONG et al. (2017)

BALLARDINI et al. (2018)

CHAN et al. (2018)
MC - Innovative approach towards mass customization in the UK chocolate industry for financial viability of supply-chain centric business models.

FL-IM - Method to simplify the identification of economically value of AM for after-sales service logistics and supply chains.

DM/DF-P/RE-S - Disruptive technologies and potential impacts on ecoperformance of entire SC, performance improvements, efficient manufacturing methods.

CR/DM - Influence of AM on spare parts supply chain.

$\mathrm{DM}-\mathrm{AM}$ as a SC indicator of evolution.

and MC/DM - AM technology adoption on SC management processes and components in an engineer-to-order environment.

$\mathrm{DM} / \mathrm{CR}$ - Value chain reconfiguration through redesign of production, distribution and logistics processes. Technological changes on SC and organization structures.

DM - Types of 3D printing services and potential implications on the SC of and FL-IM - AM influence on management of spare parts inventory.

RE-S - AM societal costs and benefits from both a monetary and a resource consumption viewpoint.

$\mathrm{DM} / \mathrm{MC}$ - Potential benefits of AM and challenges to traditional manufacturing constraints, impacts on the traditional and global SC and logistics.

DM - AM approaches with a detailed focus on the most applicable technologies to Defense Support Services. Characterization of technical aspects about centralization and independence levels between a central factory and a distributed production site for the manufacturing of spare parts leveraging AM as main production process.

RE-S/MC/DM - Research agenda to determine enablers and barriers for 3D printing to achieve a circular economy.

$\mathrm{CR} / \mathrm{FL}-\mathrm{IM} / \mathrm{MC} / \mathrm{RE}-\mathrm{S} / \mathrm{DM}$ - Insights on emerging AM processes; barriers to their adoption and a timeline of expected impacts on the supply chain in the manufacturing industry.

DM/RE-S - Framework for investment decisions based on economic value added providing assessment of value drivers in global supply chains for supporting investment decisions in 3DP technology, considering manufacturing and overall supply chain costs.

CR/DM - Framework of AM impacts on SC management.

and $\mathrm{DM} / \mathrm{RE}-\mathrm{S} / \mathrm{CR} / \mathrm{MC}$ - Overview of AM main changes in operation and supply management processes.

RE-S - Estimation of net changes in SC lead-time, life cycle primary energy consumption, greenhouse gas emissions, and life cycle costs associated with AM technologies.

DM/CR - AM influence on business ecosystem of firms, consumers, and society.

DM - Role of AM in operations, business strategies and business performance. Technological impacts.

CR/DM - SC changes associated with 3D printing technology adoption to identify the potential impacts. Driving forces for adopting digital manufacturing, present applications and future scope. Costs investigations on AM production process planning.

CR/FL-IM/DM - AM for reconfiguring SC. Existing scenarios for 3D printing in logistics. Applications in Defense Support Services

CR - Complexity reduction and impacts in SC

S-LA - Technology, business and intellectual property issues on spare parts production through AM from a digital source. Impact of 3D printing on SC. 
INDEPENDENT JOURNAL OF MANAGEMENT \& PRODUCTION (IJM\&P)

http://www.ijmp.jor.br

v. 11, n. 4, July - August 2020

ISSN: 2236-269X

DOI: 10.14807/ijmp.v11i4.1136

\begin{tabular}{|c|c|}
\hline 3) & $\begin{array}{l}\text { DM/RE-S - Verification of conceptual benefits of the AM implementation } \\
\text { spare part SC from the point of view of industry. }\end{array}$ \\
\hline CHUNG et al. (2018) & $\begin{array}{l}\text { M/CR/MC/FL-IM - Innovation in dynamic SC design and operations: } \\
\text { nnected smart factories - smart SC. }\end{array}$ \\
\hline GADGE et al. (2018) & 2/DM/RE-S/FL-IM - Impact of AM implementation on aircraft SC networks. \\
\hline GHOBADIAN et al. (2018) & E-S - AM's capabilities from its innovation and sustainability perspectives \\
\hline $\begin{array}{l}\text { HANNIBAL and KHIGHT } \\
\text { (2018) } \\
\text { MA et al. (2018) }\end{array}$ & lel. \\
\hline $\begin{array}{ll}\text { MARTINUSO and } & \\
\text { LUOMARANTA (2018) }\end{array}$ & (CM \\
\hline MUIR and HADDUD (2018) & ganizations. \\
\hline $\begin{array}{l}\text { MURMURA and BRAVI } \\
\text { (2018) } \\
\text { NGO et al. (2018) } \\
\text { ÖBERG et al. (2018) }\end{array}$ & $\begin{array}{l}\text { E-S - Potential sustainable benefits and limitations to the implementation of } \\
\text { Mrinting in the Italian wood-furniture industry. } \\
\text { M/CR/RE-S/FL-IM - Review of AM influences on evolution of business } \\
\text { odels. }\end{array}$ \\
\hline $\begin{array}{l}\text { SAVONEN et al. (2018) } \\
\text { SHUKLA et al. (2018) } \\
\text { WESTERWEEL et al. (2018) }\end{array}$ & $\begin{array}{l}\text { DM/FL-IM - Distributed manufacturing for humanitarian logis } \\
\text { FL-IM/RE-S - Innovative approach to explore and evaluate t } \\
\text { perspectives in e-commerce channels for AM. Potential of A } \\
\text { supply, life cycle cost analysis, logistics activities and producti }\end{array}$ \\
\hline $\begin{array}{l}\text { MATOS and JACINT } \\
\text { (2019) } \\
\text { AFSHARI et al. (2019) }\end{array}$ & $\begin{array}{l}\text { DM/MC/RE-S - Investigation on AM technology social impacts associated with } \\
\text { fabrication, customization, sustainability, business models and work. } \\
\text { DM/RE-S - Model for a SC enabled with AM technology and evaluation of the } \\
\text { effects of interruptions (e.g., demand fluctuations). Quantification of how } \\
\text { variations in network infrastructures, costs, and production technology could } \\
\text { influence investment decisions in favor of AM in SC costs. }\end{array}$ \\
\hline
\end{tabular}

It is possible to verify in Table 3, the interest of the academia to study which are main implications of AM in the SC and logistics. In Figure 7 is highlighted the proportion that the main theme are studied. The total percentage sum is higher than $100 \%$ since the proportional measure was been calculated regarding the themes discussed in a separately manner and not about similarity of classification.

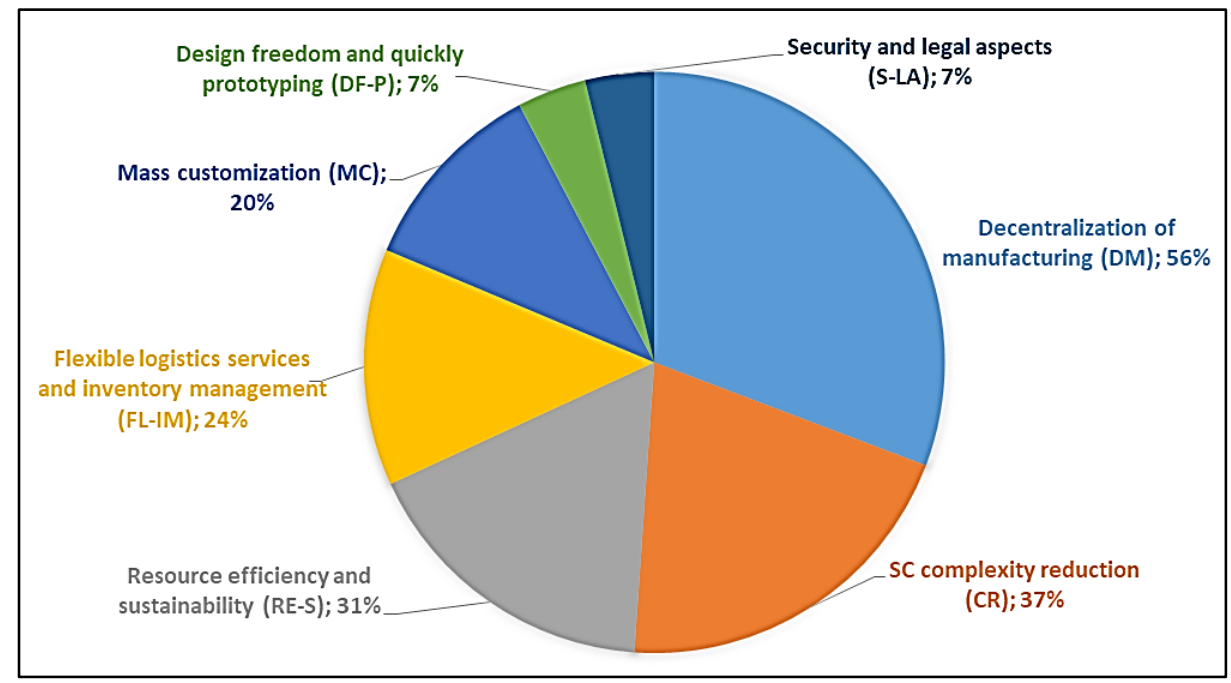

Figure 7: Proportion of the key issues covered in literature 
DOI: $10.14807 /$ ijmp.v11i4.1136

Regarding to logistics, the main theme was about reducing the transportation activities and associated costs due the proximity among producers and end-consumers of additivemanufactured products. It was also noticed that, concerning to SLA, was introduced the necessity of ensuring and controlling falsification of additive-manufactured products given the ability of AM technologies to produce numerous types of assets.

Regarding the RE, papers also covers the theme of environmental and productive sustainability, recommending the observance of wastes handling and environmental norms and regulations. Contributions of studies in terms of RE also rely on energy consumption, raw materials, and life-cycle extension of high-value products (DESPEISSE; FORD, 2015).

According to Gebler et al. (2014), the adoption AM and other advanced manufacturing technologies would in the future lead to shorter, more localized, more collaborative, and more sustainable value chains. Durach et al. (2017) argue that the expected impacts of AM technologies and the potential implications on the supply chain and logistics activities are, but not limited:

1. Structure of supply chains, for example, the location of manufacturing facilities near end-users-consumers;

2. Customer's central role in the manufacturing process, that is, new business models will be created based on the assumption that the user can create and produce the product he needs at his own home or adopting the global factory concept;

3. Logistics activities regarding transportation and storage will be also affected; and

4. New skills in the supply chain (manufacturing or services enterprises) will emerge, for example, resilience and agility.

These four guidelines cover the following implications:

- Business models that integrate customers into value creation;

- Logistics service providers who enter in the AM market by providing 3D printing services;

- Reduction of the product development process and lead-time (agile supply chain);

- Mass customized products with individual and interchangeable characteristics;

- Less or no stock of finished products (make-to-order vs. make-to-stock);

- Reduction of transport and storage costs; and 
DOI: 10.14807/ijmp.v11i4.1136

- Acquisition of CAD model data and 3D printing at home via web instead of buying finished products.

The advantages of AM technologies for producing a very varying kind of goods will alter global value chains and will create incentives for companies to adopt business and customers oriented models for both products and services supply chains due to it wideversatility on customization and unlocking of traditional manufacturing constraints (time, place and variety).

\section{FINAL CONSIDERATIONS}

The goal of this paper was to identify the implications of the AM process adoption on SC and logistics. For that purpose a systematic literature review was carried out, which allowed the identification and classification of seven major issues as follow:

- The supply chain CR, which can be achieve by replacing multi components assembly process by single-full parts production in one-step. This could contribute to increase the production lines productivity.

- The S-LA have to be attended as the arisen necessity to develop standards for regulating main issues regarding which kind of products can be free-printed or not. Users, consumers and producers-consumers need consciously follow a suitable behavior concerning this issue to avoid self-inflicted and physical damages.

- For FL-IM, focus lies in transportation activities reduction, since the consumer can produce at his own place eliminating the intermediary transportation process between producer and consumer. This will be achieved as a future trend. Regarding to the inventory cost reduction, spare parts and high variety of raw material will no longer be necessary or at least considerably reduced.

- New archetypes as MC arise versus traditional mass production. Consumers and users will be able to customize and freely design any kind of objects taking into account its own necessities.

- DM will imply producing near-at or on the final-consumption place with wide design freedom and quickly prototyping (DF-P). This approach certainly allows reducing time to market, satisfying the customer's necessities quickly or changing products design with less reprocessing work. 3D-printers will also be placed at uneasy-reachable places 
DOI: 10.14807/ijmp.v11i4.1136

or for humanitarian purposes reducing risks or delays on the supply chain of fundamental goods.

- RE-S need to be attended involving the availability of monetary capital, materials, energy, wastes management and products lifecycle and useful life extension. Approaches with this purpose have to be developed.

Bibliometric tools were used to process the data extracted form papers. A detailed data analysis allowed noting that the scientific production in the area is still relatively limited in relation to the quantity of publications and requires rapid advance. The publication trend in this area has been increasing since 2012. The most publishing journal identified is the Journal of Manufacturing Technology Management, which published 11 articles in the last 5 years. Scientific production involves 23 countries. The most contributing institutions are concentrated in the USA, UK and Germany.

The current set of results, stating that the implications of AM on the SC and logistics is an emerging and relatively novel field, may contribute to the expansion of the development of this area, including other logistics activities such as, material handling, storage, etc.

\section{REFERENCES}

ACHILLAS, C.; AIDONIS, D.; IAKOVOU, E.; THYMIANIDIS, M.; TZETZIS, D. (2015) A methodological framework for the inclusion of modern additive manufacturing into the production portfolio of a focused factory. Journal of Manufacturing Systems, v. 37, p. 328-339. https://doi.org/10.1016/j.jmsy.2014.07.014

AFSHARI, H.; JABER, M. Y.; SEARCY, C. (2019) Investigating the effects of learning and forgetting on the feasibility of adopting additive manufacturing in supply chains. Computers \& Industrial Engineering, v. 128, p. 576-590. https://doi.org/10.1016/j.cie.2018.12.069

ATTARAN, M. (2017a) Additive manufacturing: the most promising technology to alter the supply chain and logistics. Journal of Service Science and Management, v. 10, n. 3, p. 189-206. https://doi.org/10.4236/jssm.2017.103017

ATTARAN, M. (2017b) The rise of 3-D printing: The advantages of additive manufacturing over traditional manufacturing. Business Horizons, v. 60, n. 5, p. 677-688.

https://doi.org/10.1016/j.bushor.2017.05.011

BALDINGER, M.; LEVY, G.; SCHÖNSLEBEN, P.; WANDFLUH, M. (2016) Additive manufacturing cost estimation for buy scenarios. Rapid Prototyping Journal, v. 22, n. 6, p. 871-877. https://doi.org/10.1108/RPJ-02-2015-0023

BALLARDINI, R. M.;ITUARTE, I. F.; PEI, E. (2018) Printing spare parts through additive manufacturing: legal and digital business challenges. Journal of Manufacturing

Technology Management, v. 29, n. 6, p. 958-982. https://doi.org/10.1108/JMTM-12-20170270 
BARZ, A.; BUER, T.; HAASIS, H. D. (2016a) A study on the effects of additive manufacturing on the structure of supply networks. IFAC-papersonline, v. 49, n. 2, p. 72 77. https://doi.org/10.1016/j.ifacol.2016.03.013

BARZ, A.; BUER, T.; HAASIS, H. D. (2016b) Quantifying the effects of additive manufacturing on supply networks by means of a facility location-allocation model. Logistics Research, v. 9, n. 1, p. 13. https://doi.org/10.1007/s12159-016-0140-0

BEN-NER, A.; SIEMSEN, E. (2017) Decentralization and localization of production: The organizational and economic consequences of additive manufacturing (3D printing).

California Management Review, v. 59, p. 5-23. https://doi.org/10.1177/0008125617695284

BERMAN, B. (2012) 3-D printing: The new industrial revolution. Business Horizons, v. 55, n. 2, p. 155-162. http://dx.doi.org/10.1016/j.bushor.2011.11.003

BOGERS, M.; HADAR, R.; BILBERG, A. (2016) Additive manufacturing for consumercentric business models: Implications for supply chains in consumer goods manufacturing. Technological Forecasting and Social Change, v. 102, p. 225-239. https://doi.org/10.1016/j.techfore.2015.07.024

BUCKLEY, P. J. (2009a) The impact of the global factory on economic development. Journal of World Business, v. 44, p. 131-143. https://doi.org/10.1016/j.jwb.2008.05.003

BUCKLEY, P. J. (2009b) Internalisation thinking: From the multinational enterprise to the global factory. International Business Review, v. 18, p. 224-235.

https://doi.org/10.1016/j.ibusrev.2009.01.006

BUCKLEY, P. J. (2011) International integration and coordination in the global factory. Management International Review, v. 51, p. 269-283. https://doi.org/10.1007/s11575-0110075-2

BUCKLEY, P. J.; GHAURI, P. N. (2004) Globalisation: Economic geography and the strategy of multinational enterprises. Journal of International Business Studies, v. 35, p. 81-98. https://doi.org/10.1057/palgrave.jibs.8400076

BUSACHI, A.; ERKOYUNCU, J.; COLEGROVE, P.; DRAKE, V.; WATTS, C.; WILDING, S. (2018) Additive manufacturing applications in Defence Support Services: current practices and framework for implementation. International Journal of Systems Assurance Engineering and Management, v. 9, n. 3, p. 657-674. https://doi.org/10.1007/s13198-017-0585-9

BUSACHI, A.; ERKOYUNCU, J.; COLEGROVE, P.; MARTINA, F.; WATTS, C.; DRAKE, R. (2017) A review of additive manufacturing technology and cost estimation techniques for the defense sector. CIRP Journal of Manufacturing Science and Technology, v. 19, p. 117-128. https://doi.org/10.1016/j.cirpj.2017.07.001

CAMPBELL, T.; WILLIAMS, C.; IVANOVA, O.; GARRETT, B. (2011) Could 3d printing change the world? Technologies, Potential, and Implications of Additive Manufacturing. Available at: https://www.atlanticcouncil.org/wpcontent/uploads/2011/10/101711_ACUS_3DPrinting.PDF (accessed 25 January 2019).

CHAN, H. K.; GRIFFIN, J.; LIM, J. J.; ZENG, F.; CHIU, A. S. F. (2018) The impact of 3d printing technology on the supply chain: manufacturing and legal perspectives. International Journal of Production Economics, v. 205, p. 156-162. https://doi.org/10.1016/j.ijpe.2018.09.009 
CHEKUROV, S.; METSÄ-KORTELAINEN, S.; SALMI, M.; RODA, I.; JUSSILA, A. (2018) The perceived value of additively manufactured digital spare parts in industry: An empirical investigation. International Journal of Production Economics, v. 205, p. 87-97. https://doi.org/10.1016/j.ijpe.2018.09.008

CHEN, D.; HEYER, S.; IBBOTSON, S.; SALONITIS, K.; STEINGRÍMSSON, J. G.; THIEDE, S. (2015) Direct digital manufacturing: Definition, evolution, and sustainability implications. Journal of Cleaner Production, v. 107, p. 615-625. https://doi.org/10.1016/j.jclepro.2015.05.009

CHEN, Z. (2016) Research on the impact of 3D printing on the international supply chain. Advances in Materials Science and Engineering, v. 2016, p. 1-16. http://dx.doi.org/10.1155/2016/4173873

CHIU, M. C.; LIN, Y. H. (2016) Simulation based method considering design for additive manufacturing and supply chain: An empirical study of lamp industry. Industrial Management and Data Systems, v. 116, n. 2, p. 322-348. https://doi.org/10.1108/IMDS-072015-0266

CHRISTOPHER, M.; RYALS, L. J. (2014) The supply chain becomes the demand chain. Journal of Business Logistics, v. 35, n. 1, p. 29-35. https://doi.org/10.1111/jbl.12037

CHUNG, B.; IL KIM, S.; LEE, J. S. (2018) Dynamic supply chain design and operations plan for connected smart factories with additive manufacturing. Applied Sciences, v. 8, n. 4, p. 583. https://doi.org/10.3390/app8040583

DESPEISSE, M.; BAUMERS, M.; BROWN, P.; CHARNLEY, F.; FORD, S. J.; GARMULEWICZ, A.; KNOWLES, S.; MINSHALL, T. H. W.; MORTARA, L.; REEDTSOCHAS, F. P.; ROWLEY, J. (2017) Unlocking value for a circular economy through 3D printing: A research agenda. Technological Forecasting and Social Change, v. 115, p. 7584. https://doi.org/10.1016/j.techfore.2016.09.021

DESPEISSE, M.; FORD, S. (2015) The role of additive manufacturing in improving resource efficiency and sustainability. In: Umeda S., Nakano M., Mizuyama H., Hibino H., Kiritsis D., von Cieminski G. (eds) Advances in Production Management Systems: Innovative Production Management Towards Sustainable Growth. APMS 2015. IFIP Advances in Information and Communication Technology, v. 460. https://doi.org/10.1007/978-3-31922759-7_15

DURACH, C. F.; KURPJUWEIT, S.; WAGNER, S. F. (2017) The impact of additive manufacturing on supply chains. International Journal of Physical Distribution \& Logistics Management, v. 47, n. 10, p. 954-971. https://doi.org/10.1108/IJPDLM-11-20160332

DURÃO, L. F. C. S.; CHRIST, A.; ANDERL. R.; SCHÜTZER, K.; ZANCUL, E. (2016) Distributed manufacturing of spare parts based on additive manufacturing: use cases and technical aspects. Procedia CIRP, v. 57, p. 704-709.

https://doi.org/10.1016/j.procir.2016.11.122

DURÃO, L. F. C. S.; CHRIST, A.; ZANCUL, E.; ANDERL, R.; SCHÜTZER, K. (2017) Additive manufacturing scenarios for distributed production of spare parts. International Journal of Advanced Manufacturing Technology, v. 93, n. 1-4, p. 869-880. https://doi.org/10.1007/s00170-017-0555-z

DUTTA, B.; PALANISWAMY, S.; CHOI, J.; SONG, L.; MAZUMDER, J. (2011) Additive manufacturing by direct metal deposition. Advanced Material Processing, p. 33-36. 
INDEPENDENT JOURNAL OF MANAGEMENT \& PRODUCTION (IJM\&P)

http://www.ijmp.jor.br

v. 11, n. 4, July - August 2020

ISSN: 2236-269X

DOI: 10.14807/ijmp.v11i4.1136

Available at:

https:/www.asminternational.org/documents/10192/1895560/amp16905p33.pdf/d5669e7819ec-4fbd-b1ab-90298c62a0c7 (accessed 16 April 2019).

EYERS, D. R.; POTTER, A. T. (2015) E-commerce channels for additive manufacturing: An exploratory study. Journal of Manufacturing Technology Management, v. 26, n. 3, p. 390-411. https://doi.org/10.1108/JMTM-08-2013-0102

FAHIMNIA, B.; TANG, C.; DAVARZANI, H.; SARKIS, J. (2015) Quantitative models for managing supply chain risks: a review. European Journal of Operational Research, v. 247, n. 1, p. 1-15. https://doi.org/10.1016/j.ejor.2015.04.034

FAWCETT, S. E.; WALLER, M. A. (2014) Supply Chain Game Changers-Mega, Nano, and Virtual Trends-And Forces That Impede Supply Chain Design. Journal of Business Logistics, v. 35, n. 3, p. 157-164. https://doi.org/10.1111/jbl.12058

FELDMANN, C.; PUMPE, A. (2017) A holistic decision framework for 3D printing investments in global supply chains. Transportation Research Procedia, v. 25, p. 677-694. https://doi.org/10.1016/j.trpro.2017.05.451

FORD, S.; DESPEISSE, M. (2016) Additive manufacturing and sustainability: an exploratory study of the advantages and challenges. Journal of Cleaner Production, v. 137, p. 15731587. https://doi.org/10.1016/j.jclepro.2016.04.150

GAO, W.; ZHANG, Y.; RAMANUJAN, D.; RAMANI, K.; CHEN, Y.; WILLIAMS, C. B.; WANG, C. C. L.; SHIN, Y. C.; ZHANG, S.; ZAVATTIERI, P. D. (2015) The status, challenges, and future of additive manufacturing in engineering. Computer-Aided Design, v. 69, p. 65-89. https://doi.org/10.1016/j.cad.2015.04.001

GEBLER, M.; SCHOOT-UITERKAMP, A. J. M.; VISSER, C. (2014) A global sustainability perspective on 3D printing technologies. Energy Policy, v. 74, p. 158-167.

https://doi.org/10.1016/j.enpol.2014.08.033

GHADGE, A.; KARANTONI, G.; CHAUDHURI, A.; SRINIVASAN, A. (2018) Impact of additive manufacturing on aircraft supply chain performance: A system dynamics approach.

Journal of Manufacturing Technology Management, v. 29, n. 5, p. 846-865.

https://doi.org/10.1108/JMTM-07-2017-0143

GHOBADIAN, A.; TALAVERA, I.; BHATTACHARYA, A.; KUMAR, V.; GARZAREYES, J. A.; O’REGAN, N. (2018) Examining legitimatization of additive manufacturing in the interplay between innovation, lean manufacturing and sustainability. International Journal of Production Economics, p. 1-12. https://doi.org/10.1016/j.ijpe.2018.06.001

GRESS, D. R.; KALAFSKY, R. V. (2015) Geographies of production in 3D: Theoretical and research implications stemming from additive manufacturing. Geoforum, v. 60, n. 2015, p. 43-52. DOI: 10.1016/j.geoforum.2015.01.003

GUESSASMA, S.; ZHANG, W.; ZHU, J.; BELHABIB, S.; NOURI, H. (2015) Challenges of additive manufacturing technologies from an optimization perspective. International

Journal for Simulation and Multidisciplinary Design Optimization, v. 6, n. A9. https://doi.org/10.1051/smdo/2016001

GUO, N.; LEU, M. C. (2013) Additive manufacturing technology, applications and research needs. Frontiers of Mechanical Engineering, v. 8, n. 3, p. 215-243.

https://doi.org/10.1007/s11465-013-0248-8 
HANDAL, R. (2017) An implementation framework for additive manufacturing in supply chains. Journal of Operations and Supply Chain Management, v. 10, n. 2, p. 18-31. http://dx.doi.org/10.12660/joscmv10n2p18-31

HANNIBAL, M.; KNIGHT, G. (2018) Additive manufacturing and the global factory: Disruptive technologies and the location of international business. International Business Review, v. 27, p. 1116-1127. https://doi.org/10.1016/j.ibusrev.2018.04.003

HOLMSTRÖM, J.; GUTOWSKI, T. (2017) Additive manufacturing in operations and supply chain management: no sustainability benefit or virtuous knock-on opportunities? Journal of Industrial Ecology, v. 21, p. S21-S24. https://doi.org/10.1111/jiec.12580

HOLMSTRÖM, J.; HOLWEG, M.; KHAJAVI, S. H.; PARTANEN, J. (2016) The direct digital manufacturing (r)evolution: definition of a research agenda. Operations

Management Research, v. 9, n. 1-2, p. 1-10. https://doi.org/10.1007/s12063-016-0106-z

HOLMSTRÖM. J.; PARTANEN, J. (2014) Digital manufacturing-driven transformations of service supply chains for complex products. Supply Chain Management, v. 19, n. 4, p. 421430. https://doi.org/10.1108/SCM-10-2013-0387

HUANG, R.; RIDDLE, M. E.; GRAZIANO, D.; DAS, S.; NIMBALKAR, S.; CRESKO, J.; MASANET, E. (2017) Environmental and economic implications of distributed additive manufacturing: the case of injection mold tooling. Journal of Industrial Ecology, v. 21, p. S130-S143. https://doi.org/10.1111/jiec.12641

HUANG, S. H.; LIU, P.; MOKASDAR, A.; HOU, L. (2013) Additive manufacturing and its societal impact: A literature review. International Journal of Advanced Manufacturing Technology, v. 67, n. 5-8, p. 1191-1203. https://doi.org/10.1007/s00170-012-4558-5

IDA (2012) Emerging Global Trends in Advanced Manufacturing. IDA - Institute for Defense Analyses. Report IDA Paper P-4603, pp. 237.

https://www.nist.gov/sites/default/files/documents/2017/05/09/IDA-STPI-report-on-GlobalEmerging-Trends-in-Adv-Mfr-P-4603_Final2-1.pdf (accessed 15 January 2019).

JANSSEN, G. R.; BLANKERS, I. J.; MOOLENBURGH, E. A.; POSTHUMUS, A. L. (2014) TNO: The impact of 3d printing on supply chain management. Repository TU Delft Library, pp. 1-24.

https://repository.tudelft.nl/view/tno/uuid\%3Acc288b1a-837c-4f24-8504-a45bb9636b70 (accessed 17 January 2019).

JIA, F.; WANG, X.; MUSTAFEE, N.; HAO, L. (2016) Investigating the feasibility of supply chain-centric business models in 3D chocolate printing: A simulation study. Technological

Forecasting and Social Change, v. 102, p. 202-213.

https://doi.org/10.1016/j.techfore.2015.07.026

JIANG, R.; KLEER, R.; PILLER, F. T. (2017) Predicting the future of additive manufacturing: A Delphi study on economic and societal implications of 3D printing for 2030. Technological Forecasting and Social Change, v. 117, p. 84-97.

https://doi.org/10.1016/j.techfore.2017.01.006

KHAJAVI, S. H.; BAUMERS, M.; HOLMSTRÖM, J.; ÖZCAN, E.; ATKIN, J.; JACKSON, W.; LI, W. (2018) To kit or not to kit: Analyzing the value of model-based kitting for additive manufacturing. Computers in Industry, v. 98, p. 100-117.

https://doi.org/10.1016/j.compind.2018.01.022

KHAJAVI, S. H.; PARTANEN, J.; HOLMSTRÖM, J. (2014) Additive manufacturing in the spare parts supply chain. Computers in Industry, v. 65, n. 1, p. 50-63.

https://doi.org/10.1016/j.compind.2013.07.008 
KNOFIUS, N.; VAN DER HEIJDEN, M. C.; ZIJM, W. H. M. (2016) Selecting parts for additive manufacturing in service logistics. Journal of Manufacturing Technology Management, v. 27, n. 7, p. 915-931. https://doi.org/10.1108/JMTM-02-2016-0025

KOHTALA, C.; HYYSALO, S. (2015) Anticipated environmental sustainability of personal fabrication. Journal of Cleaner Production, v. 99, p. 333-344.

https://doi.org/10.1016/j.jclepro.2015.02.093

KOTHMAN, I.; FABER, N. (2016) How 3D printing technology changes the rules of the game: Insights from the construction sector. Journal of Manufacturing Technology Management, v. 27, n. 7, p. 932-943. https://doi.org/10.1108/JMTM-01-2016-0010

LAPLUME, A. O.; PETERSEN, B.; PEARCE, J. M. (2016) Global value chains from a 3D printing perspective. Journal of International Business Studies, v. 47, n. 5, p. 595-609. https://doi.org/10.1057/jibs.2015.47

LASEMI, A.; XUE, D.; GU, P. (2017) Recent development in CNC machining of freeform surfaces: a state-of-the-art review. Computer-Aided Design, v. 42, n. 7, p. 641-54. DOI: 10.1016/j.cad.2010.04.002

LI, Y.; JIA, G.; CHENG, Y.; HU, Y. (2017) Additive manufacturing technology in spare parts supply chain: a comparative study. International Journal of Production Research, v. 55, n. 5, p. 1498-1515. http://dx.doi.org/10.1080/00207543.2016.1231433

MA, J.; HARSTVEDT, J. D.; DUNAWAY, D.; BIAN, L.; JARADAT, R. (2018) An exploratory investigation of additively manufactured product life cycle sustainability assessment. Journal of Cleaner Production, v. 192, p. 55-70.

https://doi.org/10.1016/j.jclepro.2018.04.249

MACCARTHY, B. L.; BLOME, C.; OLHAGER, J.; SRAI, J. S.; ZHAO, X. (2016) Supply chain evolution - theory, concepts and science. International Journal of Operations and Production Management, v. 36, n. 12, p. 1696-1718. https://doi.org/10.1108/IJOPM-022016-0080

MARTINSUO, M.; LUOMARANTA, T. (2018) Adopting additive manufacturing in smes: exploring the challenges and solutions. Journal of Manufacturing Technology Management, v. 29, n. 6, p. 937-957. https://doi.org/10.1108/JMTM-02-2018-0030

MATOS, F.; JACINTO, C. (2019) Additive manufacturing technology: mapping social impacts. Journal of Manufacturing Technology Management, v. 30, n. 1, p.70-97. https://doi.org/10.1108/JMTM-12-2017-0263

MIGUEL, P. A. C. (2012) Metodologia de pesquisa para engenharia de produção e gestão de operações, Elsevier-ABEPRO, Rio de Janeiro.

MOHR, S.; KHAN, O. (2015) 3D printing and its disruptive impacts on supply chains of the future. Technology Innovation Management Review, v. 5, n. 11, p. 45. Available at: https://timreview.ca/sites/default/files/article_PDF/MohrKhan_TIMReview_November2015. pdf (accessed 20 May 2019).

MUIR, M.; HADDUD, A. (2018) Additive manufacturing in the mechanical engineering and medical industries spare parts supply chain. Journal of Manufacturing Technology

Management, v. 29, n. 2, p. 372-397. https://doi.org/10.1108/JMTM-01-2017-0004

MURMURA, F.; BRAVI, V. (2018) Additive manufacturing in the wood-furniture sector: Sustainability of the technology, benefits and limitations of adoption. Journal of 
ISSN: $2236-269 X$

DOI: 10.14807/ijmp.v11i4.1136

Manufacturing Technology Management, v. 29, n. 2, p. 350-371.

https://doi.org/10.1108/JMTM-08-2017-0175

NGO, T. D.; KASHANI, A.; IMBALZANO, G.; NGUYEN, K. T. Q.; HUI, D. (2018)

Additive manufacturing (3D printing): A review of materials, methods, applications and challenges. Composites Part B: Engineering, v. 143, p. 172-196.

https://doi.org/10.1016/j.compositesb.2018.02.012

NIAKI, M. K.; NONINO, F. (2017) Impact of additive manufacturing on business competitiveness: A multiple case study. Journal of Manufacturing Technology Management, v. 28, n. 1, p. 56-74. https://doi.org/10.1108/JMTM-01-2016-0001

NYMAN, H. J.; SARLIN, P. (2014) From Bits to Atoms: 3D printing in the context of supply chain strategies. $\mathbf{4 7}^{\text {th }}$ Hawaii International Conference on System Sciences 2014. p. 41904199. DOI: 10.1109/HICSS.2014.518

ÖBERG, C.; SHAMS, T.; ASNAFI, N. (2018) Additive manufacturing and business models: current knowledge and missing perspectives. Technology Innovation Management Review, v. 8, n. 6, p. 15-33. http://doi.org/10.22215/timreview/1162

OETTMEIER, K.; HOFMANN, E. (2016) Impact of additive manufacturing technology adoption on supply chain management processes and components. Journal of Manufacturing Technology Management, v. 27, n. 7, p. 944-968.

https://doi.org/10.1108/JMTM-12-2015-0113

OETTMEIER, K.; HOFMANN, E. (2017) Additive manufacturing technology adoption: an empirical analysis of general and supply chain-related determinants. Journal of Business Economics, v. 87, n. 1, p. 97-124. https://doi.org/10.1007/s11573-016-0806-8

ÖZCEYLAN, E.; ÇETINKAYA, C.; DEMIREL, N.; SABIRLIOĞLU, O. (2018) Impacts of additive manufacturing on supply chain flow: a simulation approach in healthcare industry.

Logistics, v. 2, n. 1, p. 1. https://doi.org/10.3390/logistics2010001

PARITALA, P. K.; MANCHIKATLA, S.; YARLAGADDA, P. K. D. V. (2017) Digital manufacturing- applications past, current, and future trends. Procedia Engineering, v. 174, p. 982-991. https://doi.org/10.1016/j.proeng.2017.01.250

POUR, M. A.; ZANARDINI, M.; BACCHETTI, A.; ZANONI, S. (2016) Additive manufacturing impacts on productions and logistics systems. IFAC-papersonline, v. 49, n. 12, p. 1679-1684. https://doi.org/10.1016/j.ifacol.2016.07.822

QUAN, Z.; WU, A.; KEEFE, M.; QIN, X.; YU, J.; SUHR, J.; BYUN, J-H.; KIM, B-S.; CHOU, T-W. (2015) Additive manufacturing of multi-directional preforms for composites: opportunities and challenges. Materials Today, v. 18, n. 9, p. 503-512.

https://doi.org/10.1016/j.mattod.2015.05.001

RAY, T. (2013) The 3D printed supply chain. Defense Transportation Journal, p. 14-24. Available at: https://www.ndtahq.com/defense-transportation-journal/ (accessed 10 April 2019).

ROGERS, H.; BARICZ, N.; PAWAR, K. S. (2016) 3D printing services: classification, supply chain implications and research agenda. International Journal of Physical

Distribution and Logistics Management, v. 46, n. 10, p. 886-907.

https://doi.org/10.1108/IJPDLM-07-2016-0210

ROGERS, H.; BRAZIOTIS, C.; PAWAR, K. S. (2017) Special issue on 3D printing: opportunities and applications for supply chain management. International Journal of 
DOI: 10.14807/ijmp.v11i4.1136

Physical Distribution and Logistics Management, v. 47, n. 10, p. 950-953. https://doi.org/10.1108/IJPDLM-08-2017-0248

RYAN, M. J.; EYERS, D. R.; POTTER, A. T.; PURVIS, L.; GOSLING, J. (2017) 3D printing the future: scenarios for supply chains reviewed. International Journal of Physical Distribution and Logistics Management, v. 47, n. 10, p. 992-1014. https://doi.org/10.1108/IJPDLM-12-2016-0359

SASSON, A.; JOHNSON, J. C. (2016) The 3D printing order: variability, supercenters and supply chain reconfigurations. International Journal of Physical Distribution \& Logistics Management, v. 46, n. 1, p. 82-94. https://doi.org/10.1108/IJPDLM-10-2015-0257

SAVONEN, B.; MAHAN, T.; CURTIS, M.; SCHREIER, J.; GERSHENSON, J.; PEARCE, J. (2018) Development of a resilient 3-d printer for humanitarian crisis response.

Technologies, v. 6, n. 1, p. 30. https://doi.org/10.3390/technologies6010030

SHUKLA, S.; MOHANTY, B. K.; KUMAR, A. (2018) Strategizing sustainability in ecommerce channels for additive manufacturing using value-focused thinking and fuzzy cognitive maps. Industrial Management and Data Systems, v. 118, n. 2, p. 390-411. https://doi.org/10.1108/IMDS-03-2017-0122

SILVA, J. V. L.; REZENDE, R. A. (2013) Additive manufacturing and its future impact in logistics. IFAC Proceedings, v. 6, n. 1. https://doi.org/10.3182/20130911-3-BR-3021.00126

SIRICHAKWAL, I.; CONNER, B. (2016) Implications of additive manufacturing for spare parts inventory. 3D Printing and Additive Manufacturing, v. 3, n. 1, p. 56-63. https://doi.org/10.1089/3dp.2015.0035

STRANGE, R.; ZUCCHELLA, A. (2017) Industry 4.0, global value chains and international business. Multinational Business Review, v. 25, n. 3, p.174-184. https://doi.org/10.1108/MBR-05-2017-0028

STRONG, D.; SIRICHAKWAL, I.; MANOGHARAN, G. P.; WAKEFIELD, T. (2017) Current state and potential of additive - Hybrid manufacturing for metal parts. Rapid Prototyping Journal, v. 23, n. 3, p. 577-588. https://doi.org/10.1108/RPJ-04-2016-0065

TATHAM, P.; LOY, J.; PERETTI, U. (2015) Three dimensional printing - a key tool for the humanitarian logistician? Journal of Humanitarian Logistics and Supply Chain management, v. 5, n. 2, p. 188-208. https://doi.org/10.1108/JHLSCM-01-2014-0006

THOMAS, D. (2016) Costs, benefits, and adoption of additive manufacturing: a supply chain perspective. International Journal of Advanced Manufacturing Technology, v. 85, n. 5-8, p. 1857-1876. https://doi.org/10.1007/s00170-015-7973-6

TOFAIL, S. A. M.; KOUMOULOS, E. P.; BANDYOPADHYAY, A.; BOSE, S.; O’DONOGHUE, L.; CHARITIDIS, C. (2018) Additive manufacturing scientific and technological challenges, market uptake and opportunities. Materials Today, v. 21, n. 1, p. 22-37. https://doi.org/10.1016/j.mattod.2017.07.001

WALLER, M. A.; FAWCETT, S. E. (2013) Click here for a data scientist: Big data, predictive analytics, and theory development in the era of a maker movement supply chain. Journal of Business Logistics, v. 34, n. 4, p. 249-252. https://doi.org/10.1111/jbl.12024

WALLER, M. A.; FAWCETT, S. E. (2014) Click here to print a maker movement supply chain: How invention and entrepreneurship will disrupt supply chain design. Journal of Business Logistics, v. 35, n. 2, p. 99-102. https://doi.org/10.1111/jbl.12045 
ISSN: 2236-269X

DOI: 10.14807/ijmp.v11i4.1136

WESTERWEEL, B.; BASTEN, R. J. I.; VAN HOUTUM, G. J. (2018) Traditional or additive manufacturing? Assessing component design options through lifecycle cost analysis.

European Journal of Operational Research, v. 270, n. 2, p. 570-585.

https://doi.org/10.1016/j.ejor.2018.04.015 